\title{
Cladocera (Crustacea: Branchiopoda) of Cat Tien National Park, South Vietnam
}

\author{
Artem Y. SINEV,,$^{1,2}$ Nikolai M. KOROVCHINSKY ${ }^{3}$ \\ ${ }^{1}$ South Division, Joint Russian-Vietnamese Tropical Research and Technology Center, Ho Chi Minh City, Vietnam; ${ }^{2}$ Department of \\ Invertebrate Zoology, M.V. Lomonosov Moscow State University, Leninskie Gory, 119991 Moscow; ${ }^{3}$ A.N. Severtsov Institute of \\ Ecology and Evolution, Leninsky Prospect 33, 119071 Moscow, Russian Federation \\ *Corresponding author: artemsinev@yandex.ru
}

\begin{abstract}
Cladocera of Cat Tien National Park, South Vietnam, and the surrounding agricultural area, were surveyed during the spring of 2009 (onset of the wet season) and autumn 2010 (end of the wet season). The studied water bodies included two large lakes (Bau Sau and Bau Chim), small lakes and ponds, temporary pools, rivers and streams, as well as rice fields and ponds in an agricultural area beyond the boundaries of the National Park. Fifty three species of Cladocera were found, 18 of them new for Vietnam. Distribution and taxonomical status of the species are discussed. Of the recorded species, 58.5\% (31) were found only in the National Park, 34\% (18) both in the National Park and the agricultural area, and only 7.5\% (4) exclusively in the agricultural area. Of the 20 species new for Vietnam, only one was found both in the National Park and the agricultural area, all others were found in the National Park only. Such a difference can be directly attributed to the loss of natural habitats (forest ponds and streams) in agricultural areas and to the pollution by pesticides. Our study shows the importance of surveys in pristine and protected areas, for the full evaluation of regional microcrustacean richness.
\end{abstract}

Key words: Cladocera, distribution, Cat Tien National Park, South East Asia, South Vietnam.

Received: February 2013. Accepted: June 2013.

\section{INTRODUCTION}

During the last decades, the Cladocera of mainland South East (SE) Asia have been intensely investigated. The faunistic composition of the group was re-evaluated for Thailand (Maiphae et al., 2005, 2008) and local faunas were investigated in some regions of Thailand, Cambodia and Laos (Pholpunthin, 1997; Sanoamuang, 1998; Korovchinsky and Sanoamuang, 2008b; Tanaka and Ohtaka, 2010; Van Damme et al., 2013; Kotov et al., 2013). Several taxonomic groups were revised, and several new species were described (Korovchinsky and Sanoamuang, 2008a, 2008b; Korovchinsky, 2011; Kotov and Sanoamuang, 2004a, 2004b; Kotov et al., 2005; Sinev, 2011, 2012; Sinev et al., 2007; Sinev and Sanoamuang, 2007, 2011; Sinev and Kotov, 2012; Van Damme and Sinev, 2013; Van Damme et al., 2013). At present, the cladoceran fauna of Thailand has proved to be considerably better studied than in any other country of the region - Vietnam, Malaysia, Laos, and Cambodia, while Myanmar still remain especially poorly explored (Korovchinsky, 2013).

The cladoceran fauna of South Vietnam (southernmost part - Cochinchina) was firstly studied by Stingelin (1905) who recorded 11 species, by Shirota (1966), who listed 48 taxa of species rank and by Thanh and Mien (1979), who found 30 species. Thanh et al. (1980) recorded 45 species from North Vietnam. Thanh and Hai (2001) summarised previous results and recorded 50 species for the whole country. All these authors presented only species lists or short and inadequate species descriptions and drawings which usually prevent species identification. Thus, it can be concluded that the existing data on cladoceran fauna of Vietnam require considerable reexamination. In particular, the situation can be improved by detailed faunistic study of small areas having numerous water bodies of different types and the necessary attention to systematics.

The aim of the present study was to investigate the cladoceran fauna of water bodies in Cat Tien National Park (Dong Nai province, South Vietnam) and of the surrounding agricultural area. Taxonomic studies on a few species of Cladocera of the area have already been conducted earlier (Korovchinsky, 2011; Sinev, 2011, 2012; Kotov and Sinev, 2012) or are now being published (Van Damme and Sinev, 2013). This is a pioneer study of the Cladocera in the area, and at the moment, we did not attempt to quantify the obtained information.

\section{METHODS}

Samples were collected by the first author during April-May 2009 (beginning of rain season) and September-October 2010 (the end of rain season) in Cat Tien National Park, Dong Nai province, South Vietnam, from more than 60 water bodies, including two large lakes (Bau Sau and Bau Chim), small lakes and ponds, temporary pools, rivers and streams, as well as rice fields and ponds in agricultural area beyond the boundaries of the National Park. Samples were collected with a standard plankton net 
( $25 \mathrm{sm}$ diameter, $50 \mu \mathrm{m}$ mesh size), and dip net (70 $\mu \mathrm{m}$ mesh size) and preserved in $75 \%$ ethanol or $3 \%$ formaldehyde. In locations with a complex structure of the littoral zone, up to six samples were taken simultaneously in different types of vegetation, by the type method suitable for vegetation: plants with submerged or floated leaves were collected and washed in a bucket, reed-like plants scraped by dip net, etc. Most of the permanent water bodies were sampled at least two times during each sampling season.

Animals were selected from the sample under a binocular stereoscopic microscope Biolam MBI-10, placed on slides (in a drop of a glycerol-ethanol mixture) and studied under the compound microscopes Olympus CX-41 and CX-51. Dissections were conducted by electrolytically-sharpened tungsten needles. Measurements were conducted using an eyepiece-micrometer. Drawings were made by means of camera lucida.

\section{Study sites}

Cladocerans were found in 26 locations listed below.

\section{Large permanent water bodies with well-developed littoral vegetation}

(i) Cat Tien National Park, eastern part of Bau Sau lake N 11 $27.55^{\prime}$, E $107^{\circ} 20.66^{\prime}$. A large lake (Fig. 1A) with well-developed inshore macrophyte zone and stands of reeds in the centre of the lake. During the spring, samples were taken in littoral zone, pelagic zone and the stands of reeds in the centre of the lake, and during the autumn, only in littoral zone.

(ii) Cat Tien National Park, small forest pond near Bau Sau lake, N $11^{\circ} 27.178^{\prime}$, E $107^{\circ} 20.328$. Relatively shallow pond (Fig. 1B) bordered with swamp, with humid water, bottom covered by dead leaves, and partially covered with Salvinia plants on the surface.

(iii) Cat Tien National Park, Bau Chim lake, N $11^{\circ} 28.829^{\prime}$, E $107^{\circ} 22.608^{\prime}$. Large shallow lake surrounded by wide reed stands, only littoral zone was sampled.

(iv) Ta Lai village near Cat Tien National Park, small village pond with lotus plants (Fig. 1E), N $11^{\circ} 22.253^{\prime}, \mathrm{E} 107^{\circ} 21.386^{\prime}$.

(v) Ta Lai village near Cat Tien National Park, flowthrough village pond, $\mathrm{N} 11^{\circ} 22.354^{\prime}, \mathrm{E}$ $107^{\circ} 20.773$ ', sampled during spring only.

\section{Small semi-permanent ponds without abundant macrophytes}

(vi) Cat Tien National Park, small roadside forest pond, N 11 ${ }^{\circ} 26.755^{\prime}$, E $107^{\circ} 23.180^{\prime}$.

(vii) Cat Tien National Park, small roadside forest pond
(Fig. 1C-D), N $11^{\circ} 24.444^{\prime}$, E $107^{\circ} 24.748^{\prime}$.

(viii) Cat Tien National Park, roadside pond in a former sand quarry, N $11^{\circ} 24.423^{\prime}$, E $107^{\circ} 24.790^{\prime}$.

(ix) Cat Tien National Park, small shallow forest pond, N 11을.243', E $107^{\circ} 25.172^{\prime}$.

(x) Cat Tien National Park, small roadside pool in forest, N 11'26.323', E 107²5.372'.

(xi) Cat Tien National Park, small roadside pool, N $11^{\circ} 25.775^{\prime}, \mathrm{E} 107^{\circ} 25.748^{\prime}$.

\section{Rice fields}

(xii) Ta Lai village near Cat Tien National Park, N $11^{\circ} 22.253^{\prime}$, E $107^{\circ} 21.386^{\prime}$.

(xiii) Ta Lai village near Cat Tien National Park, N $11^{\circ} 22.253 \mathrm{E} 107^{\circ} 21.386^{\prime}$.

\section{Temporary pools}

(xiv) Cat Tien National Park, temporary roadside pool, N 11 ${ }^{\circ} 26.426^{\prime}$, E $107^{\circ} 24.863^{\prime}$.

(xv) roadside pool near road between Ta Lai village and Cat Tien National Park, N $11^{\circ} 23.138^{\prime}$, E $107^{\circ} 21.774^{\prime}$.

(xvi) Cat Tien National Park, roadside pool in a pit, $\mathrm{N}$ $11^{\circ} 24.300^{\prime}, \mathrm{E} 107^{\circ} 22.468^{\prime}$.

(xvii) Cat Tien National Park, small forest roadside pool, $\mathrm{N} 11^{\circ} 26.250^{\prime}, \mathrm{E} 107^{\circ} 25.621^{\prime}$.

(xviii) Cat Tien National Park, forest flow-through pool, $\mathrm{N} 11^{\circ} 27.725^{\prime}, \mathrm{E} 107^{\circ} 20.458^{\prime}$.

(xix) Cat Tien National Park, forest flow-through pool, $\mathrm{N} 11^{\circ} 27.331^{\prime}, \mathrm{E} 107^{\circ} 20.684^{\prime}$.

(xx) VN-20 Cat Tien National Park, rock pool near Dong Nai river, N $11^{\circ} 26.527^{\prime}$, E $107^{\circ} 25.993 ’$ '.

(xxi) VN-22 Cat Tien National Park, large pool near Dong Nai river, N $11^{\circ} 26.527^{\prime}$, E $107^{\circ} 25.993^{\prime}$.

\section{Forest streams and river}

(xxii) Cat Tien National Park, small forest stream, N $11^{\circ} 27.274^{\prime}$, E $107^{\circ} 25.172^{\prime}$.

(xxiii) Cat Tien National Park, forest stream near Bau Chim lake, N $11^{\circ} 28.787^{\prime}$, E $107^{\circ} 22.744^{\prime}$.

(xxiv) Cat Tien National Park, small forest stream (Fig. 4F), N 11²6.364', E 107²5.551'.

(xxv) Cat Tien National Park, small forest stream, N $11^{\circ} 26.250^{\prime}, \mathrm{E} 107^{\circ} 25.621^{\prime}$.

(xxvi) Cat Tien National Park, littoral zone of Dong Nai river, N $11^{\circ} 26.527^{\prime}$, E $107^{\circ} 25.993$ '.

No cladocerans were found in other 36 sampling sites, mostly temporary pools, areas of the flooded forest, and several small rivers. Six ponds and four rice fields in the agricultural area with well-developed macrophytes, sampled during autumn only, also lacked Cladocera, possibly due to pollution by pesticides. 

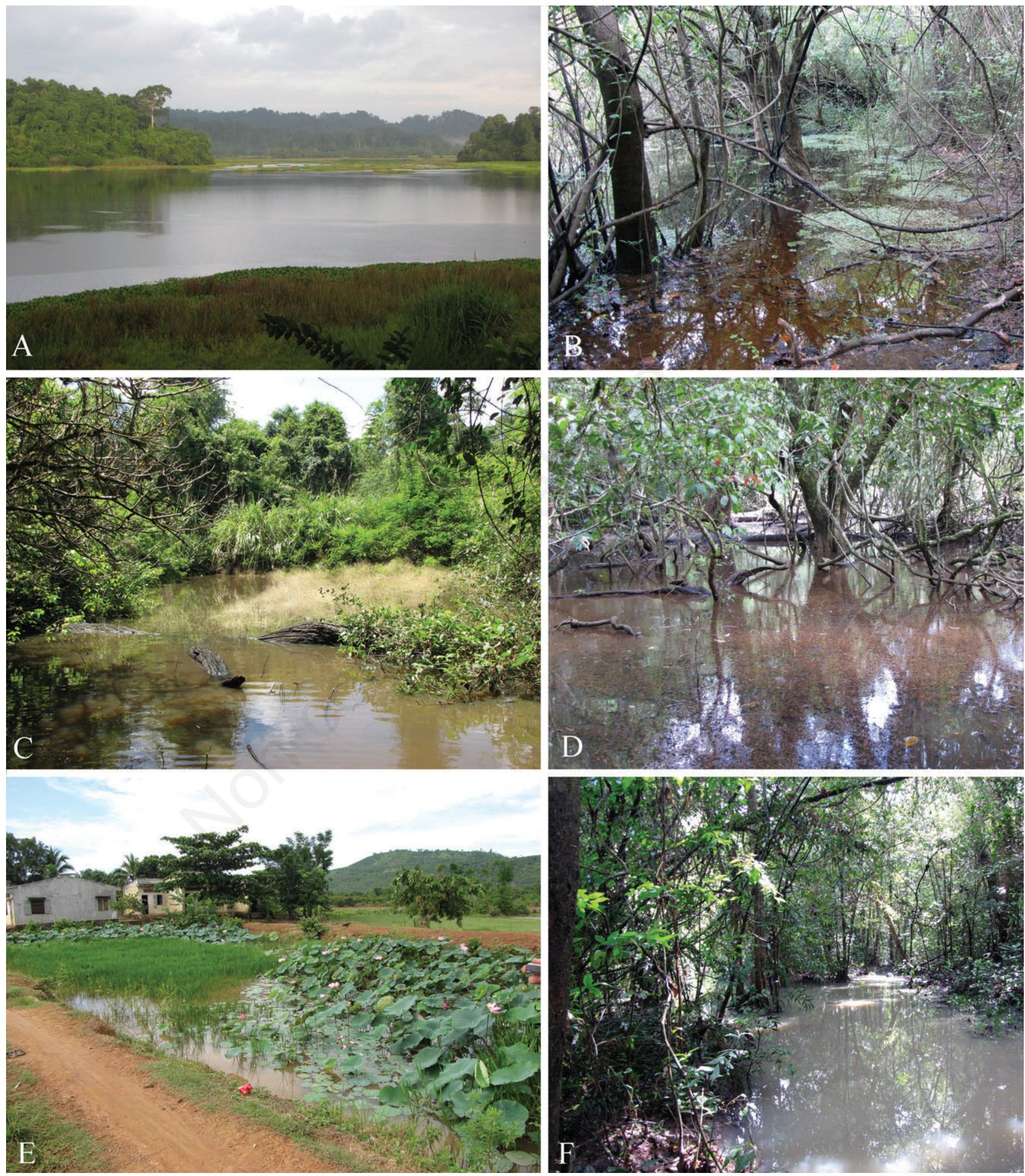

Fig. 1. Water bodies of Cat Tien National Park (Vietnam, Dong Nai province), all images taken in autumn 2010, at the end of the wet season. A) Bau Sau lake (location 1); B) forest pond (location 2); C-D) forest pond (location 5), open part and connected area of flooded forest; E) village pond in Ta Lai village (location 4); and F) flooded forest stream (locality 24). 


\section{RESULTS}

In total, 53 species of Cladocera (Tab. 1) and the conchostracan Cyclesteria hislopi have been found in the studied area. Twenty of them were not reported from Vietnam before.

\section{Family Sididae}

Diaphanosoma excisum Sars, 1885. In a wide variety of biotopes, from Bau Sau lake to small pools. Species widely distributed in tropics and subtropics of eastern hemisphere, eurytopic, often dominates zooplanktonic communities. In Thanh and Mien (1979) and Thanh et al. (1980), it was recorded under the name D. paucispinosum Brehm. For morphological description and characters of distribution in Thailand see Korovchinsky (1992) and Korovchinsky and Sanoamuang (2008b).

Diaphanosoma sarsi Richard, 1894. In different biotopes from the littoral zone of large lakes, to small forest pools. Species also widely distributed in tropics and subtropics of the eastern hemisphere but not as common as the previous species. For a morphological description and characters of its distribution in Thailand, see Korovchinsky (1992) and Korovchinsky and Sanoamuang (2008b).

Diaphanosoma dubium Manuilova, 1964. Found only in one sample from Bau Sau lake. Rather common species in South-East and East Asia, distributed far to the north up to the Amur river basin. Before, it was found very common in a few samples from North Vietnam (Korovchinsky, 2000). In Thanh and Mien (1979), Thanh et al. (1980), and Thanh and Hai (2001) it was recorded under the name of $D$. leuchtenbergianum Fischer. For detailed information see Korovchinsky $(1992,2000)$ and Korovchinsky and Sanoamuang (2008b).

Diaphanosoma volzi Stingelin, 1905. Rare species found only in one sample from small forest pool, in spring only. Widely distributed in tropical Asia, in Vietnam it was recorded for the first time. For a detailed description, see Korovchinsky (1995).

Diaphanosoma senegal isanensis Korovchinsky et Sanoamuang, 2008. Rare species, inhabiting small water bodies - small ponds and pools both forest and roadside. Rather widely distributed in SE Asia, in Vietnam it is only known in the area of Nam Cat Tien National Park. For a detailed description, see Korovchinsky and Sanoamuang (2008a).

Pseudosida szalayi Daday, 1898. Phytophilous species, inhabiting the littoral zone of lakes, as well as small water bodies (ponds and pools). Rather common species in tropical Asia, recorded before from South Vietnam as Pseudosida bidentata Herrick (Shirota, 1966; Thanh and Mien, 1979). Not yet found in northern Vietnam (Thanh et al., 1980; Thanh and Hai, 2001). For a more detailed description, see Korovchinsky (2010).
Tab. 1. List of Cladocera species found in the present study.

Family Sididae

1. Diaphanosoma dubium Manuilova, 1964 (N)

2. Diaphanosoma excisum Sars, 1885 (N, A)

3. Diaphanosoma sarsi Richard, 1894 (N, A)

4. Diaphanosoma senegal isanensis Korovchinsky et Sanoamuang, $2008(\mathrm{~N})$

5. Diaphanosoma volzi Stingelim, $1905(\mathrm{~N})^{\circ}$

6. Latonopsis australis Sars, $1888(\mathrm{~N})$

7. Pseudosida szalayi Daday, 1898 (N, A)

8. Sarsilatona cf. fernandoi Rane, 1983 (N)

Family Daphnidae

9. Ceriodaphnia cornuta Sars, 1888 (N, A)

10. Ceriodaphnia laticaudata P.E. Muller, $1867(\mathrm{~N})^{\circ}$

11. Simocephalus congener $\left(\right.$ Koch, 1841) $(\mathrm{N})^{\circ}$

12. Simocephalus $\mathrm{cf}$. heilongjiangensis Shi et Shi, $1994(\mathrm{~N}, \mathrm{~A})^{\circ}$

13. Simocephalus serrulatus (Koch, 1841) (N)

Family Moinidae

14. Moina micrura Kurz, 1874 (N, A)

15. Moinodaphnia macleayi (King, 1853) (N, A)

Family Macrotricidae

16. Grimaldina brazzai Richard, $1892(\mathrm{~N})$

17. Guernella raphaelis Richard, $1892(\mathrm{~N})^{\circ}$

18. Macrothrix triserialis (Brady, 1886) (N, A)

19. Macrothrix spinosa King, 1853 (N, A)

Family Ilyocryptidae

20. Ilyocryptus spinifer Herrick, 1882 (N, A)

Family Chydoridae

Subfamily Aloninae

21. Alona affinis (Leydig, 1860) (A)

22. Alona cambouei de Guerne and Richard, 1898 (A)

23. Alona siamensis Sinev et Sanoamuang, 2007 (A) ${ }^{\circ}$

24. Anthalona harti harti Van Damme Sinev et Dumont, 2011 (N, A)

25. Anthalona sanoamuangae Sinev et Kotov, 2012 (N)

26. Camptocercus vietnamensis Thanh, $1980(\mathrm{~N})$

27. Celsinotum macronyx (Daday, 1898) (N)

28. Coronatella cf. monacantha (Sars, 1901) (A)

29. Euryaloana orientalis (Daday, 1898) (N, A)

30. Karualona cf. karua (King, 1853) (N, A)

31. Karualona sp. $(\mathrm{N})^{\circ}$

32. Kurzia longirostris (Daday, 1898) (N)

33. Kurzia brevilabris Rajapaksa et Fernando, $1986(\mathrm{~N}, \mathrm{~A})^{\circ}$

34. Leberis diaphanus (King, 1853) (N, A)

35. Leydigiopsis $\mathrm{sp} .(\mathrm{N})^{\circ}$

36. Leydigia ciliata Gauthier, 1939 (N, A)

37. Oxyurella singalensis (Daday, 1898) $(\mathrm{N}, \mathrm{A})$

38. Nicsmirnovius eximius (Kiser, 1948) $(\mathrm{N})^{\circ}$

39. Notoalona globulosa (Daday, 1898) (N)

Subfamily Chydorinae

40. Chydorus angustirostris Frey, $1987(\mathrm{~N})^{\circ}$

41. Chydorus eurynotus Sars, 1901 (N, A)

42. Chydorus pubescens Sars, $1901(\mathrm{~N})^{\circ}$

43. Chydorus reticulatus Daday, $1898(\mathrm{~N})^{\circ}$

44. Chydorus ventricosus Daday, $1898(\mathrm{~N})^{\circ}$

45. Chydorus sp. $(\mathrm{N})^{\circ}$

46. Dadaya macrops (Daday, 1898) (N)

47. Disparalona cf. hamata (Birge, 1910) $(\mathrm{N})$

48. Dunhevedia crassa King, 1853 (N)

49. Dunhevedia serrata Daday, $1898(\mathrm{~N})^{\circ}$

50. Pleuroxus quasidenticulatus (Smirnov, 1996) (N, A) ${ }^{\circ}$

51. Pleuroxus sinkiangensis Chiang, $1964(\mathrm{~N})^{\circ}$

52. Pseudochydorus globosus (Baird, 1843) (N)

Family Bosminidae

53. Bosminopsis deitersi (Richard, 1895) (N)

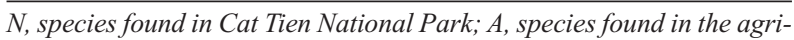
cultural area. ${ }^{\circ}$ New species for Vietnam. 
Latonopsis australis Sars, 1888. Found in Bau Sau lake in spring and in one of the temporary forest ponds in autumn. Generally this is a so far unrevised taxon of species rank (Korovchinsky, 1992) that is rather common in tropical Asia including Vietnam (Stingelin, 1905; Thanh and Mien, 1979; Thanh et al., 1980), but rare in Cat Tien National Park.

Sarsilatona cf. fernandoi Rane, 1983. Found only in autumn samples from two localities - small semi-permanent forest ponds with a thick layer of leaves on the bottom and in one water in the surrounded flooded areas. Very rare sidids in tropical Asia, found in few localities in India, South of Thailand and southern Vietnam. For a detailed description see Korovchinsky (2011).

\section{Family Daphniidae}

Ceriodaphnia cornuta Sars, 1888. One of the commonest species in the area, found in Bau Sau lake and various forest ponds, as well in rice fields and ponds in the agricultural area, frequent both in autumn and spring. Taxon of unclear status, presumed to be pantropical. Species was described from Australia. C. rigaudi Richard, 1884, described from North Vietnam, and is presumed to be a form of C. cornuta (Rzoska, 1956; Kotov and Ferrari, 2010), though future revision is needed. Recorded both in North and South Vietnam (Thanh et al., 1980, as C. rigaudi; Shirota, 1966, Thanh and Mien, 1979).

Ceriodaphnia laticaudata P.E. Müller, 1867. The species was found in a single location, an unnamed forest pond, in spring only, together with C. cornuta. It clearly differs from the latter by its larger size, lack of spine rostrum and characteristic postabdomen (Fig. 2A and 2B). This Palaearctic species was never recorded in the Indochina region, but it occurs in China (Chiang and Du, 1979). This is the first record for Vietnam.

Simocephalius congener (Koch, 1841). The species was found in a single forest pond in autumn, in Bau Chim lake in spring, and in Bau Sau lake in both seasons, common, but not abundant. Littoral species, associated with vegetation, specimens are able to attach to substrate. For a description, see Orlova-Bienkowskaia (2001). This species is very close to $S$. expinosus, already reported from Thailand (Maiphae et al., 2008), but, according to Orlova-Bienkowskaya (2001), it is a separate species, which differs from S. expinosus by the morphology of the postabdominal claw, having a pecten of 18-22 spines on the outer side instead of 8-12 (Fig. $2 \mathrm{~F}$ and $2 \mathrm{G}$ ). This is the first record for Vietnam and the Indochina region.

Simocephalius cf. heilongjiangensis Shi et Shi, 1994. Found in Bau Sau lake in autumn as rather abundant, and in a flow-through village pond in spring. Littoral species, associated with vegetation, specimens are able to attach themselves to the substrate. Studied specimens (Fig. 2C-
E), as well as specimens reported by Idris (1983) as $S$. latirostris Stingelin, 1906 from Malaysia, have elongated subrectangular rostrum (Fig. 2D), which is characteristic for S. latirostris, while in S. heilongjiangensis rostrum is long but triangular, evenly narrowing distally (Orlova-Bienkowskaya, 2001). But according to Orlova-Bienkowskaya (2001), S. latirostris is distributed in South America only, and all records of this species from SE Asia belong to $S$. heilongjiangensis instead. This is the first record for Vietnam. In our opinion, status of these two species should be clarified by the future studies.

Simocephalus serrulatus (Koch, 1841). Found in a single forest pond in spring, and in Bau Sau lake in autumn, more rare than other species of the genus. Littoral species, associated with vegetation, secimens are able to attach itself to the substrate (like $S$. latirostris above). For a description see Orlova-Bienkowskaia (2001), according to whom, this is a cosmopolitan species, common in the Oriental region. For description of the Indochina populations see Idris (1983). It is recorded both from North and South Vietnam (Thanh et al., 1980; Thanh and Mien, 1979).

\section{Family Moinidae}

Moina micrura Kurz, 1874. Abundant in temporary pools and small ponds in spring, it is the only species present in several of these locations, also found in plankton of Bau Sau lake. Males and ephippial females were recorded in several localities. The species was absent in autumn. Common species in Oriental region, mostly associated with temporary pools, rice fields and small shallow semi-permanent ponds. For a description see Goulden (1968). The species was described from Czech Republic, recorded in South and Central Europe, tropical Asia, Africa, North and South America (Goulden, 1968), but according to Petrusek et al. (2004), M. micrura is a complex of cryptic species. It is recorded both in North and South Vietnam (Thanh et al., 1980; Thanh and Mien, 1979 as M. dubia).

Moinodaphnia macleayi (King, 1853) is common in ponds and temporary pools in both forest and agricultural area, more abundant in autumn. Littoral species, associated with muddy bottom and vegetation attach itself to the substrate like Simocephalus. For a description see Goulden (1968), and for a description of the Indochina populations see Idris (1983). The species was described from Australia, and presumed to be pantropical (Goulden, 1968), populations from SE Asia are probably conspecific with Australian ones. It is recorded both in North and South Vietnam (Thanh et al., 1980; Thanh and Mien, 1979).

\section{Family Macrothricidae}

Grimaldina brazzai Richard, 1892. Several specimens were found in a single forest pond in autumn. Littoral 


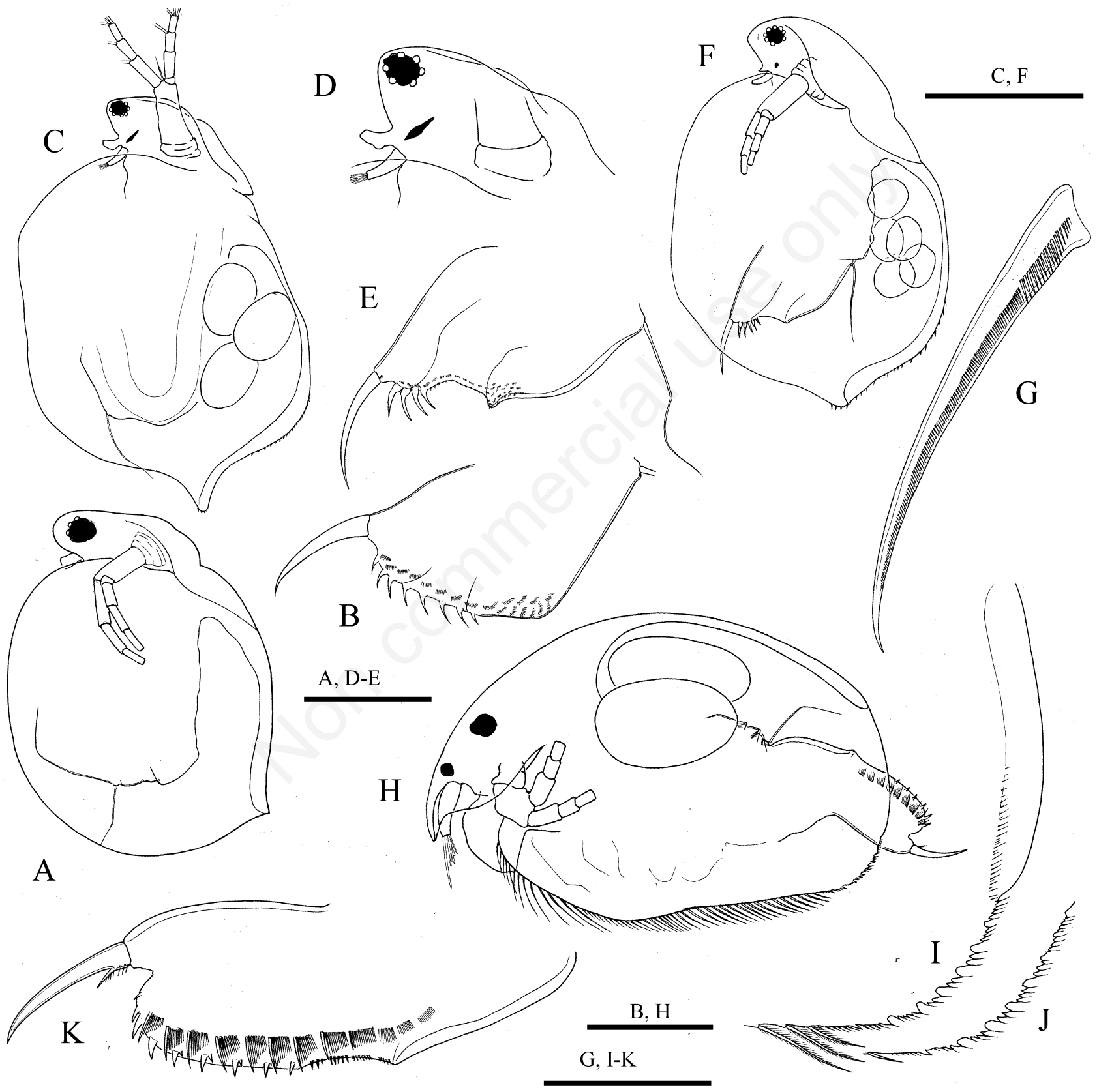

Fig. 2. Cladocera from Vietnam, Dong Nai province, Cat Tien National Park, adult parthenogenetic females. A,B) Ceriodaphnia laticaudata P.E. Müller, 1867 from locality 2. A) lateral view; B) postabdomen. C-E) Simocephalus cf. heilongjiangensis Shi et Shi, 1994. C) lateral view; D) head; E) postabdomen. F,G) Simocephalus congener (Koch, 1841) from locality 7. F) lateral view; G) postabdomen. H-K) Karualona sp. (Van Damme et al., 2013) from locality 1. H) lateral view; I,J) posteroventral corner of valves; K) postabdomen. Scale bars of $C, F)=0.5 \mathrm{~mm}$, of $A, D, E)=0.2 \mathrm{~mm}$, of $B, H)=0.1 \mathrm{~mm}$, and of $\mathrm{G}, \mathrm{I}-\mathrm{K})=0.05 \mathrm{~mm}$. 
species. For a description see Smirnov (1992) and Hollwedel et al. (2003), for a description of the Indochina populations see Idris (1983). Species presumed to be pantropical (Smirnov, 1992), yet this is most likely a complex. Recorded for South Vietnam (Shirota, 1966).

Guernella raphaelis Richard, 1892. Found only in spring in Bau Sau lake, one forest pond and one stream, rather abundant in each locality. For a description see Smirnov (1992). The species is presumed to be pantropical (Smirnov, 1992) and is rather common in the Oriental region, yet this is most likely a complex. This is the first record for Vietnam.

Macrothrix triserialis (Brady, 1896). Found in various ponds in forest and agricultural areas, Bau Sau and Bau Chim lakes. Abundant littoral species both in spring and autumn. For a description see Smirnov (1992) and Dumont et al. (2002). Species presumed to be pantropical (Smirnov, 1992), but identity of Neotropical and African populations with $M$. triserialis s. str., described from Sri Lanka, is doubted (Dumont et al., 2002). Morphology of studied specimens fully agrees with that of populations from terra typica (Dumont et al., 2002). Recorded both in North and South Vietnam (Thanh et al., 1980; Thanh and Mien, 1979). Shirota (1966) recorded a Macrothrix of the rosea-group for South Vietam, this record also probably belongs to $M$. triserialis.

Macrothrix spinosa King, 1853. Found in rice fields, a village pond, and Bau Chim lake in spring, and in a pool near Dong Nai river in autumn, yet never abundant. For a description, see Smirnov (1992) and Hollwedel et al. (2000); for a description of the Indochina populations see Idris (1983). Species presumed to be pantropical (Smirnov, 1992), common in the Oriental region. Recorded both in North and South Vietnam (Thanh et al., 1980; Thanh and Mien, 1979).

\section{Family Ilyocryptidae}

Ilyocryptus spinifer Herrick, 1882. Common in lakes, forest and village ponds, and rice fields, more abundant in autumn, when it is also encountered in forest streams. Benthic species, associated with muddy or clay bottom. For a detailed description see Kotov and Dumont (2000). The species is cosmopolitan, no evidence of non-cosmopolitanism has been found (Kotov and Dumont, 2000), common in the Oriental region.

\section{Family Chydoridae}

\section{Subfamily Aloninae}

Alona affinis (Leydig, 1860). Found in a single flowthrough pond in the agricultural area in spring. For a detailed description see Sinev (1997) and Alonso (1996). Recorded both in North and South Vietnam (Shirota, 1966; Thanh et al., 1980). Distributed in Europe, Asia,
Africa, but the taxonomic status of many populations is still unclear (Sinev, 2009).

Alona cambouei de Guerne and Richard, 1898. Found only in rice fields and one pond in the agricultural area, both in spring and autumn, not abundant. For a detailed description, see Sinev (2001) for a description of the Indochina populations see Maiphae et al. (2008). Distributed in Mediterranean region, Africa, tropical Asia, frequently associated with rice fields. Recorded both in North and South Vietnam (Thanh et al., 1980; Thanh and Mien, 1979).

Alona kotovi Sinev, 2012. Several specimens were found in a single stream in autumn. For a detailed description see Sinev (2012). The species is recorded from South Vietnam only, but possibly distributed broader, in Indochina, China, and Korea (Sinev, 2012).

Alona siamensis Sinev and Sanoamuang, 2007. Found in a single flow-through pond in the agricultural area in spring. For a detailed description see Sinev and Sanoamuang (2007). Recorded for South Vietnam by Shirota (1966) as Alonella dentifera. Distributed in Thailand and Malaysia, rare species, associated with rice fields (Sinev and Sanoamuang, 2007).

Anthalona harti harti Van Damme, Sinev et Dumont, 2011. Bau Sau lake and flow-through pond in agricultural area, only in spring. For detailed descriptions see Van Damme et al. (2011), for a description of the Indochina populations see Sinev and Kotov (2012). Recorded for North Vietnam by Thanh et al. (1980), as Biapertura pseudoverrucosa pseudoverucosa. Distributed in tropical Asia, Mediterranean region, and Africa (Van Damme et al., 2011), common in Indochina.

Anthalona sanoamuangae Sinev et Kotov, 2012. A single specimen was found in a forest stream in autumn. For a detailed description see Sinev and Kotov (2012). Rather rare species, known from Thailand and South Vietnam (Sinev and Kotov, 2012).

Camptocercus vietnamensis Thanh, 1980. Found in forest streams, common in autumn, very rare in spring. For a detailed description see Sinev (2011). According to Thanh et al., (1980), common in rivers and springs of North Vietnam. According to Sinev (2011), the distribution of this species is unclear. It was recently recorded in South Korea (Kotov et al., 2012), and thus, its range probably encompasses Indochina, South Korea and China.

Celsinotum macronyx (Daday, 1898). Several specimens were found in Bau Sau lake and in a single forest pond in spring. For a detailed description see Sinev and Kotov (2012), formerly known as Alona macronyx. Species of the Oriental region (Rajapaksa and Fernando, 1987a). This is the first record for Vietnam.

Coronatella cf. monacantha (Sars, 1901). Several specimens were found in village pond in spring. The species was described from South America, Indochina 
populations are probably not conspecific with $C$. monacantha s. str., recently revised by Sinev (2004). For a description of Indochina populations see Idris and Fernando (1981). Recorded in South Vietnam (Thanh and Mien, 1979).

Euryalona orientalis (Daday, 1898). Found in ponds both in forest and agricultural areas. Common in autumn, very rare in spring. Associated with vegetation, sometimes encountered in plankton. For a detailed description see Rajapaksa and Fernando (1987d). According to these authors, a common pantropical species. Recorded both in North and South Vietnam (Shirota, 1966; Thanh et al., 1980).

Karualona cf. karua (King, 1853). Found in rice fields and village ponds and vegetated littoral zone of Bau Sau lake, both in autumn and spring. According to Van Damme et al. (2013). South Asian populations of Karualona cf. karua differ from these of Australia (Dumont and Silva-Briano, 2000) and probably belong to a new species. Common species in Oriental region. Recorded both in North and South Vietnam (Thanh and Mien, 1979; Thanh et al., 1980).

Karualona sp. Found in Bau Sau lake in the patches of reeds, in spring only. Studied specimens (Fig. 2H-K) fully agree with those described from South Thailand as a new species by Van Damme et al. (2013). This is the first record for Vietnam.

Kurzia brevilabris Rajapaksa et Fernando, 1986. Found in small forest and village ponds, Bau Sau and Bau Chim lakes, more abundant in autumn than in spring. For a detailed description see Rajapaksa and Fernando (1986b). Species of Oriental region (Rajapaksa and Fernando, 1986b). The first record for Vietnam.

Kurzia longirostris (Daday, 1898). Found in small forest ponds and single forest stream in spring only, more rare than $K$. brevilabris. For a detailed description see Rajapaksa and Fernando (1986b). Distributed in Australia, tropical Asia and Africa. Recorded both in North and South Vietnam (Thanh and Mien, 1979; Thanh et al., 1980).

Leberis diaphanus (King, 1853). Found in Bau Sau lake, rare both in spring and autumn. Littoral species associated with vegetation. For a detailed description see Sinev et al. (2005), for a description of the Indochina populations see Idris [(1983) as Alona diaphana)], for a description of male see Sinev and Sanoamuang (2011). Distributed in Australia, tropical Asia, and Africa (Sinev et al., 2005), common in the Oriental region. Recorded both in North and South Vietnam as Alona davidi (Thanh and Mien, 1979; Thanh et al., 1980). More species of Leberis could be present in the region (Kotov et al., 2013).

Leydigiopsis sp. Found in single forest pond, common in spring, very rare in autumn. The species has been recorded from Thailand (Sanoamuang, 1998), India [Sharma and Sharma (2007) as L. curvirostris] and Cambodia [Tanaka and Ohtaka (2009) as L. curvirostris] This is the first record for Vietnam. This species is described in Van Damme and Sinev (2013); for a more detailed morphology, including the Vietnamese populations, see latter study.

Leydigia ciliata Gauthier, 1939. In autumn, common in ponds and streams both in forest and agricultural areas, as well as in rice fields. In spring, found rarely only in ponds. Benthic species, associated with muddy or clay bottom. For a detailed description see Kotov et al. (2003), for description of male see Sinev and Sanoamung (2011). Known in Africa, tropical Asia, common in Oriental region. Possibly recorded both in North and South Vietnam [Shirota (1966); Thanh et al. (1980) as L. acuticostata].

Oxyurella singalensis (Daday, 1898). Found in Bau Sau lake and small ponds both in forest and agricultural areas, common species, associated with vegetation. For a description see Smirnov, 1971; for a description of the Indochina populations see Idris (1983). Recorded both in North and South Vietnam (Thanh and Mien, 1979; Thanh et al., 1980).

Nicsmirnovius eximius (Kiser, 1948). Found in forest streams, common in autumn, but absent in spring. Bottom-dwelling rheophilous species (Van Damme et al., 2003). For a detailed description see Kotov and Sanoamuang (2004). Distributed in China and Indochina. This is the first record for Vietnam.

Notoalona globulosa (Daday, 1898) occurs in Bau Sau lake and forest ponds, rare species. Littoral, associated with vegetation. For a detailed description see Rajapaksa and Fernando (1987c). Distributed in Africa and tropical Asia, yet forms a species complex (Van Damme et al., 2013). This is the first record for Vietnam.

\section{Subfamily Chydorinae}

Chydorus angustirostris Frey, 1987. Found in forest pond in spring and in a single small flow-through temporary pool in autumn. Morphology of studied specimens (Fig. 3A-C), especially the rostrum, fully agrees with the original description (Frey, 1987). This species was described from Madhya Pradesh, India, and was never recorded after that. It is the first record for Vietnam and for the Indochina or even SE Asian region in general.

Chydorus eurynotus Sars, 1901. One of the commonest species in the area, found in all types of water bodies, except for small temporary pools, more abundant in autumn. Littoral species. For a description see Smirnov (1966); for a description of the Indochina populations see Idris (1983). This species was described from South America, presumed to be circumtropical according to Smirnov (1996), but needs a revision. Common in the Oriental region. Recorded for North Vietnam (Thanh et al., 1980).

Chydorus pubescens Sars, 1901. Several specimens were found in a forest pond in spring. The species was never described in detail, for a description see Smirnov (1996). Unlike populations recorded as Ch. cf. pubescens 


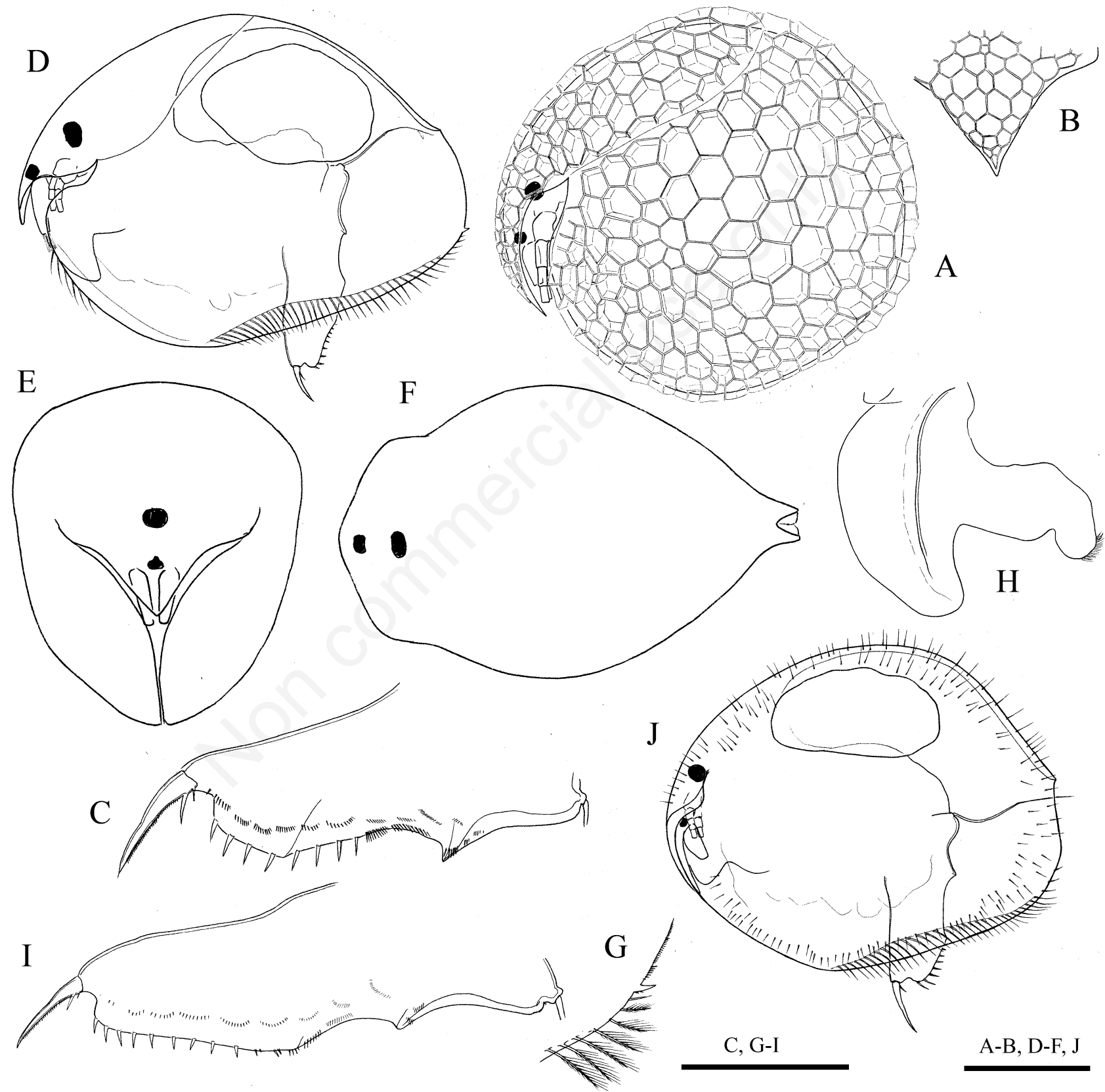

Fig. 3. Cladocera from Vietnam, Dong Nai province, Cat Tien National Park, adult parthenogenetic females. A-C) Chydorus angustirostris Frey, 1987 from locality 2. A) lateral view; B) rostrum; C) postabdomen. D-I) Chydorus n. sp. from locality 2. D-F) lateral, frontal and dorsal view of the same specimen; G) postero-ventral corner of valves; H) labrum; I) postabdomen. J) Chydorus pubescens Sars, 1901 from locality 2, lateral view. Scale bars of A,B,D,E,J)=0.1 mm, and of C, G-I) $=0.05 \mathrm{~mm}$. 
from Malaysia by Idris and Fernando (1981), studied specimens (Fig. 3J) have well-developed hair both on valves and head shield. The species was described from South America, presumed to be circumtropical according to Smirnov (1996), though it needs a revision. This is the first record for Vietnam.

Chydorus reticulatus Daday, 1898. Found in a single small flow-through temporary pool in autumn. For a description see Michael and Hann (1979), Idris and Fernando (1981), and Frey (1982). Species of Oriental region, reported for Sri Lanka, India, Thailand, Java and Malaysia. This is the first record for Vietnam.

Chydorus ventricosus Daday, 1898. Found in several small temporary pools in autumn only. For a detailed description see Michael and Hann (1979), Rajapaksa and Fernando (1986a), and Frey (1982). Species of the Oriental region, distributed from India to China, records from other continents possibly belong to close undescribed species (Rajapaksa and Fernando, 1986a). It is the first record for Vietnam.

Chydorus sp. Found in a single forest pond, both in spring and autumn. Studied specimens (Fig. 3D-I) differ from the most species of the genus by the presence of a denticle on the postero-ventral corner of valves (Fig. $3 \mathrm{G})$. It is clearly not an Ephemeroporus, which has a denticle, yet it is externally sometimes confused with Chydorus. According to Smirnov (1996), this feature is present in three species of the genus - the African $C h$. tilhoi Rey et Saint-Jean, 1969, the South American Ch. dentifer Daday, 1905, and Ch. nitidulus (Sars, 1901). The placement of the latter species - originally described as Alonella - within Chydorus is doubtful, as it has a laterally compressed body. Studied specimens differ from all these species by a very short rostrum, which is shorter than the antennule (Fig. 3D), from Ch. dentifer by sharp denticles of the valves, from $C h$. tilhoi by the labrum without denticle (Fig. $3 \mathrm{H}$ ) and by the shape of postabdomen (Fig. 3I), and from Ch. nitidulus by the globular body (Fig. 3E and 3F). Such populations of Chydorus have never been recorded in the Oriental region. We suggest it to be a new species to be described, and work on description is in progress.

Dadaya macrops (Daday, 1898). Found in Bau Sau lake and forest ponds, rare in spring, common and numerous in autumn. Littoral species, associated with the water surface. For a detailed description see Rajapaksa and Fernando (1982). The species was described from Sri Lanka, presumed to be circumtropical (Smirnov, 1996), common in the Oriental region. Recorded both in North and South Vietnam (Shirota, 1966; Thanh et al., 1980).

Disparalona cf. hamata (Birge, 1910). Rare species found in Bau Sau lake in stands of reeds in spring, and in a single forest stream in autumn. For a description see Smirnov $(1971,1996)$; for a description of the Indochina populations see Idris (1983). Recorded both in North and South Vietnam (Thanh and Mien, 1979; Thanh et al., 1980, as Pleuroxus hamatus). According to Sinev and Sanoamuang (2011), males of Thailand populations of this species significantly differ from those of typical $D$. hamata, described from North America.

Dunhevedia crassa King, 1853. Found in Bau Sau lake, both in littoral vegetation and stands of reeds in spring, but it was absent in autumn. It is less abundant than its congener, D. serrata. For a description see Smirnov (1996). The species was described from Australia, presumed to be cosmopolitan. Recorded both in North and South Vietnam (Thanh and Mien, 1979; Thanh et al., 1980).

Dunhevedia serrata Daday, 1898. Common in Bau Sau lake, both in littoral vegetation and stands of reeds in spring, in autumn it was found in one of the forest ponds. For a detailed description see Rajapaksa and Fernando (1987b). The species was described from Sri Lanka, distributed in Africa, tropical Asia and New Guinea (Smirnov, 1996). It is the first record for Vietnam.

Pleuroxus quasidenticulatus (Smirnov, 1996). Found in a single forest pond both in spring and autumn, and in a forest stream and village pond in autumn. For a description see Smirnov, 1996. The species was described from populations from Australia, Iraq and Argentina, morphology of the studied specimens (Fig. 4A-D) is especially similar to those from Iraq (Smirnov 1996). This species was recorded by Chiang and Du (1979) from China as Pleuroxus assimilis Brady, 1907, originally described from South Africa and listed as incertae sedis by Smirnov (1996). This is the first record for Vietnam.

Pleuroxus sinkiangensis Chiang, 1964. A single specimen (Fig. 4F-I) was found in Bau Sau lake in spring. This species was described from China and had not been recorded outside of the country. According to Frey (1988), P. sinkiankensis is a valid species, but it was not accepted by Smirnov (1996). It differs from P. laevis Sars by the protruding postero-dorsal corner of valves, and a very small denticle on the postero-ventral corner of valves. The species was never described in detail: for a description see Chiang (1964) and Chiang and $\mathrm{Du}$ (1979). This is the first record for Vietnam, but possibly records of $P$. laevis from the area (Shirota, 1966) belong to this species.

Pseudochydorus globosus (Baird, 1843). A single specimen (Fig. 4J-K) was found in Bau Sau lake in spring. Highly specialised scavenger, feeding on dead cladocerans and other crustaceans. For a detailed description of European populations see Van Damme and Dumont (2007). Recorded for Vietnam for the first time. Species presumed to be cosmopolitan (Smirnov, 1996), but possibly represents a species complex (Van Damme and Dumont, 2007). The herein studied specimen differs from European specimens in body shape. 


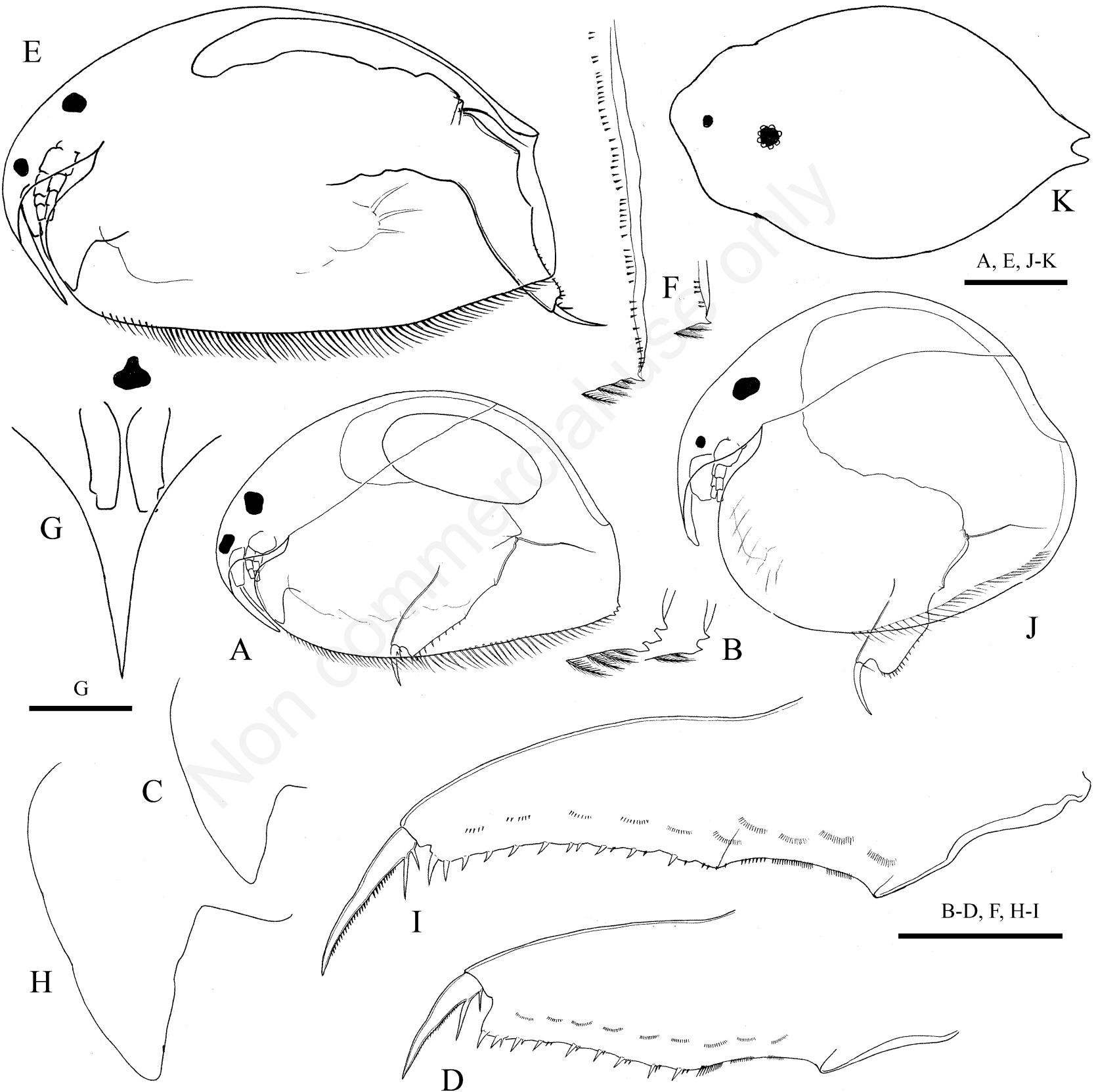

Fig. 4. Cladocera from Vietnam, Dong Nai province, Cat Tien National Park, adult parthenogenetic females. A-D) Pleuroxus quasidenticulatus Smirnov, 1996, from locality 2. A) lateral view; B) postero-ventral corners of left and right valves of the same specimen; C) labrum; D) postabdomen. E-I) Pleuroxus sinkiangensis Chiang, 1964 from locality 1. E) lateral view; F) posteriventral corners of left and right valves of the same specimen; G) rostrum; H) labrum; I) postabdomen. J,K) Pseudochydorus globosus (Baird, 1843) from locality 1 , lateral and dorsal view of the same specimen. Scale bars of A,E,J,K) $=0.1 \mathrm{~mm}$, and of G and B-D, F, H-I)=0.05 mm. 


\section{Family Bosminidae}

Bosminopsis deitersi (Richard, 1895). Common in plankton of Bau Sau lake in spring, in autumn found in the littoral zone of Bau Chim lake, and several specimens were found in Dong Nai river. Common planktonic species, presumed to be cosmopolitan, widely distributed in the Oriental region. For a detailed description see Kotov (1997a, 1997b). Recorded both in North and South Vietnam (Shirota, 1966; Thanh et al., 1980).

\section{Species distributions in the study area}

In the largest studied water body, Bau Sau lake (locality 1), 25 species of Cladocera (Tab. 2) and Cyclesteria hislopi were encountered in the littoral zone. During the spring, the pelagic plankton of the lake was composed of four species, Diaphanosoma excisum, Diaphanosoma dubium, Bosminopsis deitersi and Moina micrura. During the spring, the cladoceran community of the littoral zone was different from that of inshore reed stands (Tab. 2). In autumn, only the littoral zone of the lake was accessible because the water level increases. This time, its community differed from that observed of spring, most notably by the presence of Simocephalus spp. Three species, Diaphanosoma dubium, Karualona sp., and Pleuroxus sinkiankensis, were found only in this lake.

In the unnamed forest pond near Bau Sau lake (locality 2) the diversity of Cadocera was similar (26 species), but species composition was significantly different (Tab. 2). Five species of Cladocera, Diaphanosoma volzi, Grimaldina brazzai, Leydigiopsis sp., Chydorus pubescens, and Chydorus sp. n. were found only here. In spring, the number of species was greater than in autumn.

In the littoral zone of Bau Chim lake (locality 3 ) and in the village ponds (localities 4-5), the number of Cladocera species was much lower than in the two previous localities (Tab. 2). In all these water bodies, which are characterised by the presence of abundant macrophytes, Cladocera diversity in spring was higher than in autumn.

During the spring, the forest ponds without abundant macrophytes (localities 6-11) were relatively small in size, with almost no submerged plants present and the bottom in all these localities were muddy, with some amount of dead leaves. Cladoceran communities were similar, composed mostly of planktonic species, Diaphanosoma spp. and Ceriodaphnia cornuta (Tab. 3). In autumn, ponds appeared to connect with the flooded forests and expanding into the surrounding areas (especially localities 7, 8, 10). Cladoceran communities here were more diverse, composed mostly of littoral species, their composition varying from pond to pond. In most ponds, except for pond 9, the number of species in autumn was greater than in spring. Eighteen Cladocera species were encountered in these habitats and all of them were also found in other water bodies.

In spring, only four of the sampled temporary pools (15, 16, 17 and 22) contained cladocerans, namely $D i$ aphanosoma excisum, D. sarsi, D. senegal, and Moina micrura, whose abundance was high in each locality $(D$. excisum and M. micrura were found in locality $15, D$. sarsi, M. micrura in locality 17 and 21, D. sarsi and D. senegal in locality 16). We presume these pools were filled during the early start of spring rains. In autumn, most of the temporary pools connect with the flooded areas. Of these spring pools, two $(16,17)$ lacked Cladocera, while Moinodaphnia macleayi and Ceriodaphnia cornuta were present in locality 15, and Ilyocryptus spinifer and Ch. ventricosus in locality 21 . In total, in autumn 14 species of Cladocera (Diaphanosoma sarsi, D. senegal, Ceriodaphnia cornuta, Moinodaphnia macleayi, Macrothrix triserialis, M. spinosa, Ilyocryptus spinifer, Leydigia ciliata, Karualona cf. karua, Chydorus angustirostris, Ch. reticulatus, Ch. ventricosus, Dadaya macrops, Ephemeroporus barroisi) were recorded in pools, not inhabited in the spring (pools 14, 1820). Abundance was relatively low in each locality, only several specimens of each species were collected during each of the sampling. Of the species recorded here, only one, Chydorus reticulatus, was never encountered in other types of water bodies.

Cladocera occur only in two of the sampled rice fields. During the spring, 10 species of cladocerans ( $D i$ aphanosoma excisum, D. sarsi, Moina micrura, Moinodaphnia macleayi, Macrothrix triserialis, M. spinosa, Ilyocryptus spinifer, Oxyurella singalensis, Karualona cf. karua, Leydigia ciliata) and Cyclesteria hislopi were found here, of which Diaphanosoma excisum dominated. During the autumn, only three species (Diaphanosoma sarsi, Ceriodaphnia cornuta and Macrothrix triserialis) were present here.

During the spring, forest streams were shallow, with average depth approximately less than $0.3 \mathrm{~m}$, but after each rain, their volume significantly and rapidly increased. Three of four sampled forest streams were devoid of Cladocera during the spring. Three species, Guernella raphaelis, Camptocercus vietnamensis, and Kurzia longirosris were found in one locality (22) where the stream created numerous comparatively deeper semi-stagnant areas with leave litter on the bottom. During the autumn, all forest streams became deeper (average depth reached approximately up to $0.7-0.8 \mathrm{~m}$ ), less subjected to water level fluctuations. Here and there large areas of amphibiotic macrophytes developed, but the stream bottom was mostly muddy, lacking leave litter. In all four streams, the cladoceran communities were dominated by the specialised rheophilous species Nicsmirnovius eximius. Camptocercus vietnamensis was present in three localities $(22,24,25)$, Leydigia ciliata in two localities $(22,23)$, and other species in a single locality each 
(Anthalona sanoamuangae and Disparalona cf hamata in locality 22, Alona kotovi in locality 23, Pleuroxus quasidenticulatus in locality 24). No Cladocera were found in the sampled rivers. Of nine species, four (Nicsmirnovius eximius, Camptocercus vietnamensis, Anthalona sanoamuangae and Alona kotovi) were found in the more shallow streams only.

\section{DISCUSSION}

Our results significantly increase the number of cladoceran species known from South Vietnam, but, nevertheless, the local species richness appears still considerably less than what has been recorded for Thailand (Maiphae et al., 2008; Van Damme et al., 2013). This study, together

Tab. 2. Cladocera (plus Cyclestheria hislopi) of permanent water bodies with well-developed macrophytes (localities 1-5).

\begin{tabular}{|c|c|c|c|c|c|c|c|c|c|c|}
\hline Locality & $1 \mathrm{~L}$ & $1 \mathrm{R}$ & $1 \mathrm{~L}$ & 2 & 2 & 3 & 3 & 4 & 4 & 5 \\
\hline Season & $\mathrm{S}$ & $\mathrm{S}$ & A & $\mathrm{S}$ & A & $\mathrm{S}$ & A & $\mathrm{S}$ & A & $\mathrm{S}$ \\
\hline Diaphanosoma dubium & & $\mathrm{c}$ & & & & & & & & \\
\hline Diaphanosoma excisum & & $\mathrm{c}$ & & & & & & & $\mathrm{c}$ & \\
\hline Diaphanosoma sarsi & & & & & & & $\mathrm{c}$ & & $\mathrm{c}$ & \\
\hline Diaphanosoma volzi & & & & $\mathrm{c}$ & & & & & & \\
\hline Latonopsis australis & $\mathrm{r}$ & & & & & & & & & \\
\hline Pseudosida szalyi & & & & $\mathrm{c}$ & $\mathrm{c}$ & $\mathrm{c}$ & $\mathrm{c}$ & $\mathrm{c}$ & $\mathrm{c}$ & $\mathrm{a}$ \\
\hline Sarsilatona cf. fernandoi & & & & & $\mathrm{r}$ & & & & & \\
\hline Ceriodaphnia cornuta & & & $\mathrm{c}$ & $\mathrm{c}$ & $\mathrm{c}$ & & $\mathrm{c}$ & & $\mathrm{c}$ & \\
\hline Ceriodaphnia laticaudata & & & & $\mathrm{c}$ & & & & & & \\
\hline Simocephalus congener & & & & $\mathrm{c}$ & $\mathrm{c}$ & $\mathrm{c}$ & & & & \\
\hline Simocephalus heilongjiangensis & & & $\mathrm{a}$ & & & & & & & $\mathrm{c}$ \\
\hline Simocephalus serrulatus & & & $\mathrm{c}$ & $\mathrm{c}$ & & & & & & \\
\hline Moinodaphnia macleayi & & & & $\mathrm{c}$ & & $\mathrm{c}$ & $\mathrm{c}$ & $\mathrm{c}$ & & $\mathrm{a}$ \\
\hline Grimaldina brazzai & & & & & $\mathrm{r}$ & & & & & \\
\hline Guernella raphaelis & $\mathrm{c}$ & & & $\mathrm{c}$ & & & & & & \\
\hline Macrothrix triserialis & $\mathrm{a}$ & $\mathrm{a}$ & a & & $\mathrm{c}$ & $\mathrm{c}$ & & $\mathrm{a}$ & $\mathrm{a}$ & $\mathrm{a}$ \\
\hline Macrothrix spinosa & & & & & & $\mathrm{c}$ & & $\mathrm{c}$ & $\mathrm{a}$ & \\
\hline Ilyocryptus spinifer & $\mathrm{c}$ & & $\mathrm{c}$ & $\mathrm{c}$ & $\mathrm{c}$ & $\mathrm{c}$ & & $\mathrm{c}$ & $\mathrm{c}$ & $\mathrm{c}$ \\
\hline Alona affinis & & & & & & & & & & $\mathrm{r}$ \\
\hline Alona cambouei & & & & & & & & & $\mathrm{c}$ & $\mathrm{c}$ \\
\hline Alona siamensis & & & & & & & & & & $\mathrm{r}$ \\
\hline Anthalona harti & $\mathrm{r}$ & & & & & & & & & $\mathrm{c}$ \\
\hline Coronatella cf. monacantha & & & & & & & & $\mathrm{c}$ & $\mathrm{c}$ & \\
\hline Celsinotum macronyx & $\mathrm{r}$ & & & $\mathrm{r}$ & & & & & & \\
\hline Euryalona orientalis & & & & & $\mathrm{c}$ & & & & & $\mathrm{c}$ \\
\hline Karualona cf. karua & $\mathrm{c}$ & $\mathrm{c}$ & $\mathrm{c}$ & & & & & $\mathrm{c}$ & $\mathrm{c}$ & $\mathrm{c}$ \\
\hline Karualona sp. & & $\mathrm{c}$ & & & & & & & & \\
\hline Kurzia brevilabris & $\mathrm{c}$ & & $\mathrm{c}$ & $\mathrm{c}$ & & $\mathrm{c}$ & & $\mathrm{c}$ & $\mathrm{c}$ & \\
\hline Kurzia longirostris & & & & $\mathrm{c}$ & & & & & & \\
\hline Leberis diaphanus & $\mathrm{c}$ & $\mathrm{r}$ & $\mathrm{r}$ & $\mathrm{c}$ & & & & & & $\mathrm{a}$ \\
\hline Leydigiopsis sp. & & & & $\mathrm{c}$ & $\mathrm{r}$ & & & & & \\
\hline Notoalona globulosa & $\mathrm{r}$ & $\mathrm{c}$ & $\mathrm{c}$ & $\mathrm{c}$ & $\mathrm{c}$ & $\mathrm{r}$ & & & & \\
\hline Oxyurella singalensis & $\mathrm{c}$ & $\mathrm{c}$ & $\mathrm{c}$ & $\mathrm{c}$ & $\mathrm{c}$ & & & & & \\
\hline Chydorus angustiformis & & & & $\mathrm{c}$ & & & & & & \\
\hline Chydorus cf. eurynotus & $\mathrm{a}$ & $\mathrm{c}$ & a & $\mathrm{c}$ & $\mathrm{c}$ & $\mathrm{c}$ & & & & $\mathrm{c}$ \\
\hline Chydorus pubescens & & & & $\mathrm{r}$ & & & & & & \\
\hline Chydorus sp. & & & & $\mathrm{c}$ & $\mathrm{c}$ & & & & & \\
\hline Ephemeroporus barroisi & $\mathrm{c}$ & & & & & & & & & \\
\hline Dadaya macrops & $\mathrm{c}$ & & & $\mathrm{r}$ & $\mathrm{c}$ & & & & & \\
\hline Disparalona hamata & & $\mathrm{r}$ & & & & & & & & \\
\hline Dunhvedia crassa & $\mathrm{r}$ & $\mathrm{c}$ & & & & & & & & \\
\hline Dunhvedia serrata & $\mathrm{c}$ & $\mathrm{c}$ & & & & & & & & \\
\hline Pleuroxus quasidenticulatus & & & & $\mathrm{c}$ & $\mathrm{c}$ & & & & $\mathrm{c}$ & \\
\hline Pleuroxus sinkiankensis & & $\mathrm{r}$ & & & & & & & & \\
\hline Bosminopsis deitersi & & $\mathrm{c}$ & & & & & $\mathrm{r}$ & & & \\
\hline Cyclesteria hislopi & $\mathrm{c}$ & $\mathrm{c}$ & & $\mathrm{c}$ & & & & $\mathrm{c}$ & & \\
\hline
\end{tabular}

$1 L$, littoral samples of locality 1 (Bau Sau lake); $1 R$, samples in inshore reed stands of locality $1 ; S$, spring; A, autumn; c, common species, present in all taken samples, no less than 10 specimens collected during each season; $r$, rare species, only 1-4 specimens present in one of the taken samples; a, abundant species, more than 30 specimens per sample. 
with several previous taxonomical studies (Korovchinsky, 2011; Sinev, 2012; Sinev and Kotov, 2012) increased the number of valid species known from Vietnam from 50 (Thanh and Hai, 2001) to 71. It should be noted, that most of new records belong to littoral species, which can be easily overlooked if sampling is concentrated mostly on pelagic fauna and require special efforts to collect. Considering the zooplankton rarity concept established by Hessen and Walseng (2008), such comparatively small number of known species reflects low intensity of faunistic studies in the country and not the true richness of fauna. We believe that most species known from Thailand and other countries of the region will be also eventually found in Vietnam.

The most diverse cladoceran fauna was encountered in two water bodies: Bau Sau lake (locality 1) - a large natural lake in the central part of the National Park; and a small forest lake nearby (locality 2) - which was the richest in rare species. Conditions in the latter locality was similar to that observed in peat swamps of South Thailand (Van Damme et al., 2013), habitats which appear to be hotspots of cladoceran biodiversity. The fauna of forest ponds and temporary pools was composed of common SE Asian species, while forest streams have specific faunas, dominated by rheophilous species. Diversity of Cladocera in water bodies of Cat Tien National Park was significantly greater than in the surrounding agricultural area. Thirty one $(58.5 \%)$ of 53 recorded species (Tab. 1) were found only in National Park, 18 (34\%) both in National Park and agricultural area, and only four (7.5\%) (Alona cambouei, Coronatella cf. monacantha, Alona affinis, Alona siamensis) exclusively in the agricultural area. Of the 18 species new to Vietnam, only one (i.e. Alona siamensis) was found in the agricultural area, and one (i.e. Pleuroxus quasidenticulatus) both in the National Park and the agricultural area. All the others were found in the National Park only. With the exception of Alona siamensis, all species found in agricultural areas are common species for SE Asia. Lower diversity in the agricultural areas reflects the low diversity of its water habitats. In particular, ponds with humic water and natural streams are absent in the area. On the other hand, fertilisers and pesticides also can reduce the aquatic invertebrate diversity (Simpson and Roger, 1995; Schäfer et al., 2011), and, from our observations, they are used quite liberally by the local farmers. In autumn, sampling in six village ponds and four rice fields have not yielded Cladocera at all, despite the abundance of macrophytes in some of them.

Our data shows significant differences between species compositions in spring and autumn. Of 53 species found, 12 are rare, encountered in limited numbers in one-two samples only, eight of them (Alona affinis, Alona siamensis, Celsinotum macronyx, Coronatella cf. monacntha, Karualona sp., Chydorus pubescens, Pleuroxus sinkiangensis, Pseudochydorus globosus) only in spring, and four (Grimaldina brazzai, Alona kotovi, Anthalona sanoamuangae, Chydorus reticulatus) only in autumn. Obviously, data on these species is not enough to analyse their seasonal distribution, yet it is clear that the two seasons differ. Of 41 more common species, 33 were encountered during both seasons, five species (Diaphanosoma volzi, Ceriodaphnia laticaudata, Moina micrura, Guernella raphalis, Kurzia longirostris) only in spring, and three species (Sarsilatona

Tab. 3. Cladocera of forest ponds without well-developed macrophytes (localities 6-11).

\begin{tabular}{|c|c|c|c|c|c|c|c|c|c|c|c|c|}
\hline Locality & 6 & 6 & 7 & 7 & 8 & 8 & 9 & 9 & 10 & 10 & 11 & 11 \\
\hline Season & $\mathrm{S}$ & A & $\mathrm{S}$ & A & $\mathrm{S}$ & A & S & A & $\mathrm{S}$ & A & $\mathrm{S}$ & A \\
\hline Diaphanosoma excisum & $\mathrm{a}$ & & $\mathrm{a}$ & $\mathrm{c}$ & $\mathrm{a}$ & $\mathrm{c}$ & $\mathrm{a}$ & & & $\mathrm{c}$ & & \\
\hline Diaphanosoma sarsi & $\mathrm{c}$ & & & & & & & & & & $\mathrm{a}$ & $\mathrm{a}$ \\
\hline Diaphanosoma senegal isanensis & $\mathrm{c}$ & & & $\mathrm{c}$ & & $\mathrm{c}$ & $\mathrm{c}$ & & & $\mathrm{c}$ & & $\mathrm{c}$ \\
\hline Pseudosida szalayi & & & & $\mathrm{c}$ & & & & & & & & \\
\hline Sarsilatona cf. fernandoi & & & & $\mathrm{c}$ & & & & & & & & \\
\hline Ceriodaphnia cornuta & $\mathrm{c}$ & $\mathrm{a}$ & & $\mathrm{a}$ & & $\mathrm{a}$ & $\mathrm{c}$ & $\mathrm{c}$ & $\mathrm{c}$ & & $\mathrm{c}$ & $\mathrm{c}$ \\
\hline Moinodaphnia macleayi & $\mathrm{c}$ & & & $\mathrm{c}$ & & $\mathrm{c}$ & & & & & $\mathrm{c}$ & \\
\hline Moina micrura & & & & & & & $\mathrm{c}$ & & & & & \\
\hline Macrothrix triserialis & & & $\mathrm{c}$ & & & & & & & & & \\
\hline Ilyocryptus spinifer & & $\mathrm{c}$ & & $\mathrm{c}$ & & $\mathrm{r}$ & $\mathrm{r}$ & & & & & \\
\hline Euryalona orientalis & & $\mathrm{a}$ & & & & & & & & $\mathrm{c}$ & & \\
\hline Kurzia brevilabris & & & & $\mathrm{c}$ & & $\mathrm{r}$ & & & & $\mathrm{c}$ & & \\
\hline Kurzia longirosris & & & & & & & & & & & $\mathrm{c}$ & \\
\hline Leydigia ciliata & & & & & & & & & & & & $\mathrm{c}$ \\
\hline Chydorus cf. eurynotus & & $\mathrm{a}$ & & $\mathrm{c}$ & & $\mathrm{c}$ & $\mathrm{c}$ & & $\mathrm{c}$ & $\mathrm{c}$ & & \\
\hline Chydorus ventricosus & & & & & & & & & & & & $\mathrm{c}$ \\
\hline Dadaya macrops & & & & & & & & & & $\mathrm{c}$ & & \\
\hline Dunhvedia serrata & & & & & & & & & & $\mathrm{c}$ & & $\mathrm{c}$ \\
\hline
\end{tabular}

S, spring; A, autumn; c, common species, present in all taken samples, no less than 10 specimens collected during each season; $r$, rare species, only 1 4 specimens present in one of the taken samples; a, abundant species, more than 30 specimens per sample. 
cf. fernandoi, Chydorus ventricosus, Nicsmirnovius eximius) only in autumn. The disappearance of Moina micrura at the end of wet season is especially striking, possibly it is caused by the loss of preferred habitats. Separated stagnant temporary pools and small ponds, preferred by the species, generally disappear, being flooded by running waters. The presence of numerous gamogenetic specimens in several populations of $M$. micrura during spring also suggests that conditions for the species became less favorable with the onset of the rainy season.

\section{CONCLUSIONS}

Our study shows the importance of surveys in pristine and protected areas for the full evaluation and diversity of microcrustacean biota, as shown by the cladocerans here. Destruction of natural habitats in agricultural areas can lead to significant loss of Cladocera and other microcrustacean biodiversity. As shown by Van Damme et al. (2013), one of such habitats (i.e. lowland swamps) is rapidly disappearing in South Thailand. Revealed differences between spring and autumn faunas of Cladocera suggest that only long-term collecting efforts can fully give an insight in the local faunas. The cladoceran fauna of Vietnam is far from well-studied, and future efforts are needed to fully understand the species richness.

\section{ACKNOWLEDGMENTS}

We are grateful to Prof. La-orsri Sanoamuang (Maha Sarakham University, Thailand) and Dr. Maria K. Hołyńska (Institute of Zoology, Warsaw, Poland), the organisers of the FISA workshop, for the invitation to participate in the meeting, hospitality during the event, and financial support. We are thankful to the staff of the Joint Russian-Vietnamese Tropical Research and Test Center, South Division, Ho Chi Minh City and the staff of Cat Tien National Park. Special thanks to Anna B. Vasilieva, Eduard A. Galoyan, Igor V. Palko, Alexey A. Polilov and Nikolai A. Poyarkov for help during the sampling. The study was supported by the Russian Foundation for Basic Research (grant 12-04-00207-a for both authors and grant13-04-01065-a for the first author). The study was partly supported by the Ministry of Education and Science of the Russian Federation (14.740.11.1049, 8334).

\section{REFERENCES}

Alonso M, 1996. [Crustacea, Branchiopoda. 7. Fauna Iberica]. [Book in Spanish]. Museo National de Ciencias Natural ed., Madrid: 486 pp.

Chiang S, Du N, 1979. [Fauna Sinica, Crustacea, Freshwater Cladocera]. [Article in Chinese]. Science Press, Peking: 297 pp.

Chiang SC, 1964. [Notes on the Cladocera of Sinkiang]. [Article in Chinese]. Acta Zool. Sinica 16:70-88.

Dumont HJ, Silva-Briano M, 2000. Karualona n.gen. (Anomopoda: Chydoridae), with a description of two new species, and a key to all known species. Hydrobiologia 435:61-82.

Dumont HJ, Silva-Briano M, Babu KKS, 2002. A re-evaluation of the Macrothrix rosea-triserialis group, with the description of two new species (Crustacea Anomopoda: Macrothricidae). Hydrobiologia 467:1-44.

Frey DG, 1982. The reticulated species of Chydorus (Cladocera, Chydoridae): two new species with suggestions of convergence. Hydrobiologia 93:255-279.

Frey DG, 1987. The North American Chydorus faviformis (Cladocera, Chydoridae) and the honeycombed taxa of other continents. Philos. T. Roy. Soc. B 315:353-402.

Frey DG, 1988. Separation of Pleuroxus laevis Sars, 1861 from two resembling species in North America: Pleuroxus straminius Birge, 1879 and Pleuroxus chiangi n.sp. (Cladocera, Chydoridae). Can. J. Zool. 66:2534-2563.

Goulden CE, 1968. The systematics and evolution of the Moinidae. T. Am. Philos. Soc. 58:1-101.

Hessen DO, Walseng B, 2008. The rarity concept and the commonness of rarity in freshwater zooplankton. Freshwater Biol. 53:2026-2035.

Hollwedel W, Kotov AA, Brandorff GO, 2003. Cladocera (Crustacea: Branchiopoda) from the Pantanal (Brazil). Arthropoda Sel. 12:67-93.

Idris BAG, 1983. Freshwater zooplankton of Malaysia (Crustacea: Cladocera). Penerbit University Pertanian Malaysia, ed. Serdang: $153 \mathrm{pp}$.

Idris BAG, Fernando CH, 1981. Cladocera of Malaysia and Singapore with new records, redescriptions, and remarks on some species. Hydrobiologia 77:233-256.

Korovchinsky NM, 1992. Sididae and Holopediidae. Guides to the identification of the microinvertebrates of the continental waters of the world 3. SPB Acad. Publ., The Hague: $82 \mathrm{pp}$.

Korovchinsky NM, 1995. Redescription of Diaphanosoma volzi Stingelin, 1905 (Crustacea: Daphniiformes: Sididae), with remarks on comparative morphology, biology and geographical distribution. Hydrobiologia 315:189-201.

Korovchinsky NM, 2000b. Redescription of Diaphanosoma dubium Manuilova, 1964 (Branchiopoda: Ctenopoda: Sididae), and description of a new, related species. Hydrobiologia 441:73-92.

Korovchinsky NM, 2010. A taxonomic revision of Pseudosida szalayi Daday, 1898 (Crustacea: Cladocera: Sididae) over its Asian range, with focus on the northernmost populations first recorded from the Amur River basin (Far East of Russia). Zootaxa 2345:1-18.

Korovchinsky NM, 2011. Description of Sarsilatona cf. fernandoi (Rane, 1983) (Crustacea: Cladocera: Sididae) found in the south of Vietnam. Zootaxa 3129:29-38.

Korovchinsky NM, 2013. Cladocera (Crustacea: Branchiopoda) of South East Asia: history of explorations, taxon richness and notes on zoogeography. J. Limnol. 72(Suppl.2):e7.

Korovchinsky NM, Sanoamuang L, 2008a. Diaphanosoma senegal Gauthier, 1951 (Crustacea: Cladocera: Sididae) in South-East Asia. Zootaxa 1695:53-60.

Korovchinsky NM, Sanoamuang L, 2008b. Overview of Sididae (Crustacea: Cladocera: Ctenopoda) of Northeast and East Thailand, with description of a new species of the genus $\mathrm{Di}$ aphanosoma. Zootaxa 1682:45-61. 
Kotov AA, 1997a. Structure of thoracic limbs of Bosminopsis deitersi Richard, 1895. Hydrobiologia 360:25-32.

Kotov AA, 1997b. Studies on the morphology and variability of Amazonian Bosminopsis deitersi Richard, 1895 (Anomopoda Bosminidae). Arthropoda Sel. 6:3-30.

Kotov AA, Dumont HJ, 2000. Analysis of the Ilyocryptus spinifer-species group (Anomopoda, Branchiopoda), with description of a new species. Hydrobiologia 428:85-113.

Kotov AA, Ferrari FD, 2011. The taxonomic research of Jules Richard on Cladocera (Crustacea: Branchiopoda) and his collection at the National Museum of Natural History, U.S.A. Zootaxa 2551:37-64.

Kotov AA, Maiphae S, Sanoamuang L, 2005. Revision of Macrothrix paulensis-like species (Anomopoda, Cladocera, Branchiopoda) in Asia, and phylogeny of the paulensisgroup. Arch. Hydrobiol. Suppl. 151:269-299.

Kotov AA, Sanoamuang L, 2004a. Comments on the morphology of Nicsmirnovius eximius (Kiser, 1948) (Aloninae, Anomopoda, Cladocera) in Thailand, with description of its male. Hydrobiologia 519:117-125.

Kotov AA, Sanoamuang L, 2004b. Ilyocryptus thailandensis sp.nov. (Cladocera: Anomopoda: Ilyocryptidae) from North Thailand. Int. Rev. Hydrobiol. 89:206-214.

Kotov AA, Stifter P, Sanoamuang L, 2005. Notes on the genus Ilyocryptus Sars, 1862 (Cladocera: Anomopoda: Ilyocryptidae). 8. Ilyocryptus isanensis sp. n. from North-East Thailand. Arthropoda Sel. 14:229-239.

Kotov AA, Van Damme K, Bekker EI, Siboualipha S, Silva-Briano M, Ortiz AA, de la Rosa RG, Sanoamuang L. 2013. Cladocera (Crustacea: Branchiopoda) of Vientiane province and municipality, Laos. J. Limnol. 72(Suppl.2):e6.

Maiphae S, Pholpuntin P, Dumont HJ, 2005. Species richness of the Cladocera (Branchiopoda: Anomopoda and Ctenopoda) in southern Thailand, and complementarity with neighboring regions. Hydrobiologia 537:147-156.

Maiphae S, Pholpuntin P, Dumont HJ, 2008. Taxon richness and biogeography of the Cladocera (Crustacea: Ctenopoda, Anomopoda) of Thailand. Ann. Limnol.-Int. J. Lim. 1:31-41.

Michael RG, Hann BJ, 1979. On the resurrection of the Cladoceran species Chydorus reticulatus Daday, 1898 (Chydoridae, Cladocera) and its relationship to Chydorus ventricosus Daday, 1898. Hydrobiologia 65:225-232.

Orlova-Bienkowskaja MY, 2001. Cladocera: Anomopoda Daphniidae: genus Simocephalus. Guides to the identification of the microinvertebrates of the continental waters of the world 17. Backhuys Publ., Leyden: 130 pp.

Petrusek A, Černy M, Audenaert E, 2004. Large intercontinental differentiation of Moina micrura (Crustacea: Anomopoda): one less cosmopolitan cladoceran? Hydrobiologia 526:73-81.

Pholpunthin P. 1997. Freshwater zooplankton (Rotifera, Cladocera and Copepoda) from Thale-Noi, South Thailand. J. Sci. Soc. Thailand 23:23-34.

Rajapaksa R, Fernando CH, 1982. The first description of the male and ephippial female of Dadaya macrops (Daday, 1898) (Cladocera, Chydoridae), with additional notes on this common tropical species. Can. J. Zool. 60:1841-1850.

Rajapaksa R, Fernando CH, 1986a. A review of the systematics and distribution of Chydorus ventricosus Daday, 1898, with the first description of the male and redescription of the species. Can. J. Zool. 64:818-832.
Rajapaksa R, Fernando CH, 1986b. Tropical species of Kurzia (Crustacea, Cladocera) with a description of Kurzia brevilabris sp. nov. Can. J. Zool. 64:2590-2602.

Rajapaksa R, Fernando CH, 1987a. A note on Alona macronyx Daday, 1898 (Crustacea, Cladocera), a rare species from the Oriental Region. Can. J. Zool. 65:216-218.

Rajapaksa R, Fernando CH, 1987b. A redescription of Euryalona orientalis (Daday, 1898), with a consideration of the other species in the genus Euryalona (Cladocera: Chydoridae). Hydrobiologia 150:75-90.

Rajapaksa R, Fernando CH, 1987c. Redescription and assignment of Alona globulosa Daday, 1898 to a new genus Notoalona and a description of Notoalona freyi sp. nov. Hydrobiologia 144:131-153.

Rajapaksa R, Fernando CH, 1987d. Redescription of Dunhevedia serrata Daday, 1898 (Cladocera, Chydoridae) and a description of Dunhevedia americana sp. nov. from America. Can. J. Zool. 65:432-440.

Rzoska I, 1956. On the variability and status of the Cladocera Ceriodaphnia cornuta and C. rigaudi. J. Nat. Hist. 9:505510.

Sanoamuang L, 1998. Contribution to the knowledge of the Cladocera of north-east Thailand. Hydrobiologia 362:45-53.

Schäfer RB, van den Brink PG, Liess M, 2011. Impacts of pesticides on freshwater ecosystems, p. 111-137. In: F. SánchezBayo, P.G. van den Brink, and M.M. Reinier (eds.), Ecological impacts of toxic chemicals. Bentham ed.

Sharma BK, Sharma S, 2007. New records of two new interesting chydorid cladocerans (Branchiopoda: Cladocera: Chydoridae) from floodplain lakes of Assam, India. Zoo's Print J. 22:2799-2801.

Shirota A, 1966. The plankton of South Viet-Nam. Freshwater and marine plankton. Overseas Technical Cooperation Agency Publ., Tokyo: 489 pp.

Simpson IC, Roger PA, 1995. The impact of pesticides on nontarget aquatic invertebrates in wetland rice fields: a review, p. 249-270. In: P.A. Pingali and P.A. Roger (eds.), Impact of pesticides on farmer health and environment. International Rice Research Institute ed.

Sinev AY, 1997. Review of the affinis-group of Alona Baird, 1843, with the description of a new species from Australia (Anomopoda Chydoridae). Arthropoda Sel. 6:47-58.

Sinev AY, 2001. Separation of Alona cambouei Guerne and Richard, 1893 from Alona pulchella King, 1853 (Branchiopoda, Anomopoda, Chydoridae). Arthropoda Sel. 10:5-18.

Sinev AY, 2004. Redescription of a South American cladocera, Alona monacantha Sars, 1901 (Branchiopoda, Anomopoda, Chydoridae). Arthropoda Sel. 13:7-12.

Sinev AY, 2009. Cladocerans of the Alona affinis (Leydig, 1860) group from South Africa. Zootaxa 1990:41-54.

Sinev AY, 2011. Redescription of the rheophilous cladocera Camptocercus vietnamensis Thanh, 1980 (Cladocera: Anomopoda: Chydoridae). Zootaxa 2934:53-60.

Sinev AY, 2012. Alona kotovi sp.n., a new species of Aloninae (Cladocera: Anomopoda: Chydoridae) from South Vietnam. Zootaxa 3475:45-54.

Sinev AY, Kotov AA, 2012. New and rare Aloninae (Cladocera: Anomopoda: Chydoridae) from Indochina. Zootaxa 3334:1-28.

Sinev AY, Nachai S, Sanoamuang L, 2007. Occurrence of the 
Australian cladoceran Armatalona macrocopa (Sars, 1894) (Cladocera: Anomopoda: Chydoridae) in Thailand. Invertebr. Zool. 4:25-29.

Sinev AY, Sanoamuang L, 2007. Alona siamensis sp.n., a new species of Cladocera from South-East Asia, related to Alona dentifera (Sars, 1901) (Anomopoda: Chydoridae). Arthropoda Sel. 16:143-150.

Sinev AY, Sanoamuang L, 2011. Hormonal induction of males as a method for studying tropical cladocerans: description of males of four chydorid species (Cladocera: Animopoda: Chydoridae). Zootaxa 2826:45-56.

Sinev AY, Van Damme K, Kotov AA, 2005. Redescription of tropical-temperate cladocerans Alona diaphana King, 1853 and Alona davidi Richard, 1895 and their translocation to Leberis Smirnov, 1989 (Branchiopoda:Anomopoda: Chydoridae). Arthropoda Sel. 14:183-205.

Smirnov NN, 1971. [Chydoridae of the world. Fauna of the USSR 101]. [Book in Russian]. Nauka, Leningrad: 531 pp.

Smirnov NN, 1992. The Macrothricidae of the world. Guides to the identification of the microivertebrates of the continental waters of the world 1. SPB Acad. Publ., The Hague: 143 pp.

Smirnov NN, 1996. Cladocera: the Chydorinae and Sayciinae (Chydoridae) of the World. Guides to the identification of the microinvertebrates of the continental waters of the world, 11. SPB Acad. Publ., Amsterdam: 197 pp.

Stingelin T. 1905. [Untesuchungen uber die Cladocerenfauna von Hinterindien, Sumatra und Java, nebst eineb Beitrage zur Cladoceren kenntnis von Hawaii Inseln (Reise von Dr. Walter Volz)]. [Article in German]. Zool. Jahrb. Allg. Zool.
$21: 327-370$

Tanaka S, Ohtaka A, 2010. Freshwater Cladocera (Crustacea, Branchiopoda) in Lake Tonle Sap and its adjacent waters in Cambodia. Limnology 11:171-178.

Thanh DN, Hai HH, 2001. Freshwater crustaceans. Fauna of Viet Nam. 5. Science and Technique Publ., Hanoi: 239 pp.

Thanh DN, Mien PV, 1979. [Contribution to the study of freshwater zooplankton of South Vietnam]. [Article in Vietnamese]. Biol. Rev. 1:1-6.

Thanh DN, Rai TT, Mien PV, 1980. 0The freshwater invertebrates of North Vietnam. Hanoi: 573 pp.

Van Damme K, Dumont HJ, 2007. Limb morphology of the carnivorous anomopods Anchistropus emarginatus Sars, 1862 and Pseudochydorus globosus (Baird, 1843) (Crustacea: Branchiopoda: Anomopoda). Ann. Limnol.-Int. J. Lim. 43:271-284.

Van Damme K, Maiphae S, Sa-ardrit P, 2013. Inland swamps in South East Asia harbour hidden cladoceran diversities: species richness and the description of new paludal Chydoridae (Crustacea: Branchiopoda: Cladocera) from Southern Thailand. J. Limnol. 72(Suppl.2):e10.

Van Damme K, Sinev AY, 2013. Tropical Amphi-Pacific disjunctions in the Cladocera (Crustacea: Branchiopoda). J. Limnol. 72(Supp1.2):e11.

Van Damme K, Sinev AY, Dumont HJ, 2011. Separation of Anthalona gen.n. from Alona Baird, 1843 (Branchiopoda: Cladocera: Anomopoda): morphology and evolution of scraping atenothermic alonines. Zootaxa 2875:1-64. 